\title{
EDUCATIONAL AND TRAINING REQUIREMENTS OF FARMERS IN AL-TA'MIM GOVERNORATE IN THE FIELD OF USING \& MAINTAINING CENTER PIVOT SPRINKLER IRRIGATION SYSTEMS AND THEIR RELATION WITH SOME FACTORS
}

Aamel F. AlAbbassi

College of Agric. \& Forestry, Mosul Univ., Iraq
Salah J. AlDawoody

College of Agric., Kirkuk Uni., Iraq

\begin{abstract}
The main objectives of this research are to assess the educational and training requirements of farmers in Al-Ta'mim governorate in the field of using and maintaining the center pivot sprinkler irrigation systems and identifying the differences between these requirements according to some independent factors. The research sample consisted of 142 farmers representing $60 \%$ of the total number of farmers who were using these systems. The data was collected through a questionnaire form and utilizing the Borich equation. After testing the validity and reliability of the questionnaire, the data acquisition commenced through personal interview, the data then were analyzed by using analysis of variance and step-wise regression analysis. The results showed that $94 \%$ of farmers require medium to high levels of education and training and that there are significant differences in these requirements according to: educational level, number of months of utilizing the system, annual income, size of holding, and communication level with information sources. Yet, there are no significant differences according to readiness to change and social norms. It is also found that the (number of months of utilizing the system) is the most contributing factor in the interpretation of the variance of the educational and training requirements.
\end{abstract}

\section{INTRODUCTION}

Water resources are considered to be the main axis of the potential agricultural development as it is one of the important agricultural inputs if not the most. Thus, the availability of this input for the agricultural sector is a main factor contributing in horizontal and vertical expansion of this sector (AOAD, 2001). While agriculture in some regions depends on rainfalls, which are unpredictable, the regulating of utilizing irrigation water is considered to be an important issue (AOAD,1999). This deems necessarily the need for developing a long term agricultural strategy aiming to direct the consumption of water and rise the efficiency of its use by introducing modern irrigation technologies and by providing the required information and skills to the farmers who need them by training to attain agricultural development (AOAD, 2001). The design of strategic policies and plans for the development of the agricultural sector in Iraq must assume dimensions that are relevantly linked to water resources and their scientific measurement from the aspects of quantity, quality and rationed use.Iraq has sought to achieve these goals through a number of programs and projects including the development of a modern irrigation technology project that aims to develop the efficiency of irrigation systems by replacing the

Part of M.Sc. dissertation of the second author.

Received 1/9/2008 accepted 14/1/2009 
traditional irrigation methods with highly efficient modern methods in order to confront urgent challenges and difficult times that might arise in the face of the agriculture sector like drought, and low levels of water in the Tigris and the Euphrates (Mohammed, 1999). These technologies have the advantages of achieving the economy's goals through using water and making it accessible according to the rationed allocation for each type of yield in addition to use these technologies in which lands can't be cultivated by the traditional methods for reasons related to the composition of the soil and land topography (Al Abbassi et al., 2002) The project of developing modern irrigation technologies in Al- Ta'mim governorate is still in its beginnings. Although the farmers who have received center- pivot sprinkler irrigation systems have in fact used them but the production is still lower than the aspired levels a reason, which may be due to the lack of experience, information and skills in using these complex systems from one side and because the farmers haven't been exposed to training courses on these systems from the other. Being newly introduced to the governorate, modern technological equipment need trained workers (Al Samarai \& Al Gadri, 1990) thus farmers must be trained and prepared to use and maintain these systems efficiently.In order to devise training courses for training farmers in this field, their training and educational needs should be expounded acutely and determined clearly which were the motivation for the researchers that urged them to carry out this study.

Previous studies carried out in this field (Al-Abbassi et al., 2002) found that the farmer's training requirements for operating and maintaining center-pivot sprinkler irrigation systems were as following: knowledge of water distribution in the field, using the irrigation system in undulated lands, using fertilizers, herbicides and insecticides with irrigation water and knowing the lowest rate of water supply that insures the operation of the system in addition to other requirements. The studies that considered the relation between the training requirements and some independent factors found a negative significant relation between the training requirements and the education level of the respondents. Al-Layla \& Al-Abbassi (1990), Al-Mamoori (1995), while Ibrahim (1991), Al Juboori (2000) found a positive significant relation between them and in the same time Al-Abbassi et al. (2002) didn't find any relation .Other studies found an inverse significant relation between the average training requirement and the annual income (Ibrahim, 1991), while Al-Abbassi et al. (2002) found a positive significant relation, and Al Marsomi (1994) found a positive significant relation between the training needs and the size of farm holding for which Al Juboori (2000) found no relation . Al Badri (1995) found a positive significant relation between the traiing needs and agricultural information sources, and Al Shadayda (1999) found a negative significant relation. Al-Abbassi et al. (2002) didn't find any significant differences between the training needs according to agricultural information sources. Some studies showed a positive correlation between the training needs and the readiness to change including Al Azawi (1999), while Al Badri (1995) found a negativ relation. The study in general aimed to achieve the following: Assessing the educational and training requirements of the farmers in the governorate of Al Ta'mim in general in the field of using and maintaining the center-pivot sprinkler irrigation systems and in each item in this field, determine the differences between educational and 
training requirements of the farmers according to the following factors: educational level, number of months of utilizing the system, annual income, size of holding, communication level with information sources, readiness to change, and social norms. A regression analysis was used for the relation between the educational and training requirements of the farmers and a number of independent factors..

\section{MATERIALS AND METHODS}

The population of the research consisted of all the farmers in Al Ta'mim governorate who have received and actually operated center-pivot sprinkler irrigation systems. The number of farmers amounted to 236 farmer distributed among 11-administration unit. A systematic random sample with a size of $60 \%$ was selected resulting in 142 farmers in the study. A two-part questionnaire form was used for data collection. The first part included the independent study variables, the level of education was measured according to the following: illiterate, reades \& writes, primary education, secondary school, high school, institute, and college with a score of one, two, three, four, five, six and seven respectively. The number of months of utilizing the systems was calculated from the date of receiving the system and operating it until 1/7/2002, and the income from agricultural and nonagricultural sources estimated in the value if Iraqi Dinars, and the size of agricultural holding in Donums. The level of communication with information sources from which the farmers receive information concerning using \& maintaining the center-pivot sprinkler irrigation systems are from TV and radio agricultural programs, research centers and colleges, all types of publications, friends and neighbors, agricultural extension workers, agricultural division, the agricultural directorate in the governorate put in a scale of: Always, Sometime, scarcely and I do Not Communicate, and the scores for these levels were: four, three, two, one respectively. The readiness to change was measured through eight items, four positive and the other four negative with the alternative answers of: agree, not sure, don't agree with a scores of: three, two, one respectively for the positive items and the opposite for the negative items, the sum of the scores represents the degree of readiness to change. The second part of the questionnaire form was dedicated for measuring the educational and training requirements of the farmers in the field of using and maintaining the center-pivot sprinkler irrigation systems. After studying the relevant literature, seeking the advice of some specialists, holding personal interviews with farmers using the systems and those working in the operating center of the project in the governorate of al Ta'mim, besides a number of irrigation system ,manufacturing companies, the researchers determined 69 items related to using and maintaining the center-pivot sprinkler irrigation systems and presented them to specialists in this field for correction who added, deleted, or modified some of the items until the final number of items adopted were 50 items. Two scales accompanied the items, the first is to measure the degree of information which the farmer processes for the item and is devided into four levels: high, moderate, low, non-existing attributed with the scores: four, three, two, one respectively. The second scale is to measure the degree of importance of the item according to the farmers point of view. and it is devided into 
four levels: high importance, moderate, low, not important, attributed with the scores: four, three, two, one, respectively.

Borich's equation (1980) was adopted as an indirect method to measure the educational and training requirements of farmers as following:

$\mathrm{Tn}=(\mathrm{In}-\mathrm{Kn}) \mathrm{I} \mathrm{G}$

Where:

$\mathrm{T}_{\mathrm{n}}=$ The educational and training requirements.

$I_{n}=$ The degree of importance of the item from the farmers point of view.

$\mathrm{K}_{\mathrm{n}}=$ The knowledge degree of the farmers concerning the item.

$\mathrm{I} \mathrm{G}=$ the average of item importance for all respondents.

After completing the questionnaire form, it was presented to a number of specialists in agricultural extension, education and psychology in order to determine the face validity. Presenting the questionnaire to specialists in irrigation systems is considered as content validity also. A random sample of 30 farmers representing $13 \%$ of systems users was chosen, and data was collected from this limited sample in order to determine the clarity of the questionnaire from the farmer's point of view, and in order to determine the reliability of the scales in the study .Split-half method was used utilizing person's equation and corrected by using SpearmanBrown equation. The reliability was determined as stated and was found to be 0.93 for the scale measuring the level of knowledge and skills of the farmers in the field of using \& maintaining the center-pivot sprinkler irrigation systems, and 0.76 for the scale of readiness for change, and 0.75 for social norms. After completing the scientific conditions that must be available in the data collecting tool, the data was collected through personal interview for the period between 20/11/2002 until $15 / 2 / 2003$ The most important statistical tools used in analyzing the data were: arithmetic mean, standard deviation, analysis of variance, and step-wise multiple regression.

\section{RESULTS AND DISCUSSION}

First: Assessing the educational and training requirements of the farmers in $\mathrm{Al}$ Ta'mim governorate in the field of using \& maintaining the center-pivot sprinkler irrigation systems: The results have shown that the highest degree for the level of educational and training requirements was 9.27 and the lowest was 0.43 with an arithmetic mean of 5.68 and standard deviation of 1.54 degree. The respondents were classified into three categories according to the level of requirements as shown in (table 1).

Table (1): Classification of the respondents according to their level of educational and training requirements

\begin{tabular}{|c|l|c|c|}
\hline \multicolumn{1}{|c|}{ Category } & \multicolumn{1}{c|}{ level of educational and training requirements } & No. & $\%$ \\
\hline $1^{\text {st }}$ category & Low ( less than 3.50) degree & 8 & 5.63 \\
\hline $2^{\text {nd }}$ category & Moderate $(3.50-6.50)$ degree & 80 & 56.34 \\
\hline $3^{\text {rd }}$ category & high( more than 6.50$)$ degree & 54 & 38.03 \\
\hline & Total & 142 & $100 \%$ \\
\hline
\end{tabular}


It is clear from (table 1) that $94 \%$ of the respondents have moderate-high requirements which means that they lack knowledge, experiences and skills in the field of using \& maintaining the center-pivot sprinkler irrigation systems but can acquire them through education and training. The results had also shown that the items which came first in the list of educational and training requirements of the farmers was the item of (method of using herbicides and insecticides with irrigation water) with an average of 9.74 and standard deviation 1.81 degree, due to the difficult of the subject and its need for scientific and technical skills that the farmers do not have, besides the importance of the subject to the farmers, this result agreed with Al Abassi et al.(2002), the item that came last in the requirements was the item of (knowing the appropriate time to operate the system) with an average of 1.65 and standard deviation of 2.29 degrees. This result indicated that the requirements of learning this subject is the least important because the farmers already know it. (Appendix 1) elucidates the educational and training requirements of the farmers in all the items including knowledge and skills in the field of using \& maintaining the center-pivot sprinkler irrigation systems.

Second: determining the differences in the educational and training requirements of the farmers according to some factors: Below we present the results that clear the differences in the educational and training requirements of the farmers according to some personal, social and communicational characteristics as shown in (table 2). It is obvious that significant differences exist between the average of educational and training requirements of the farmers according to their levels of education because these requirements increase with lower educational level maybe because farmers with higher education levels can read and implements the manuals and leaflets in addition to other agricultural extension bulletins, at the same time they are capable of comprehencing the guidelines set fourth by the engineers and technicians when installing the systems. The results agreed with the findings of Al layla \& Al Abbassi (1990) Al Mamori (1995).

The results also showed significant differences in the averages of educational and training requirements according to the number of months using of the system as the educational and training requirements decrease with the increase of number of months of use which may stem from the fact that farmers have gained more experience in operating and maintaining the systems. It was also found that the average of requirements decrease with the increase of the annual income with high significant differences between income levels in agreement with Ibrahim (1991). The reason maybe due to the high living standard that urges the farmers to explore new agricultural methods. (Table 2) also shows differences in educational and training requirements of the farmers with different agricultural holding and the average of requirements decrease with the increase of the agricultural holding. This finding confirms the finding of Al Guboori (2000), the reason maybe the increase of the agricultural holding requires more systems and then increase the need for those technicians to operate the systems which makes the farmers perceive less need for training. The results indicate that the average education and training requirements decrease with the increase of communication with agricultural information sources, an agreement with Al Shadayda (1999) which may stem from the multiplicity of information sources concerning the system leading to increase in the knowledge and 
skills lessening the educational and training requirements. The result also show that no significant differences exit in educational and training requirements of the farmers according to the readiness to change which doesn't confirm with the finding of Al Azawi (1999) maybe because the irrigation system have been newly introduced to the region and that farmers although are ready to change but they don't have information and experience therefore they need training.

Table (2): Differences in the Educational and training Requirements of the Farmers According to some factors

\begin{tabular}{|c|c|c|c|c|}
\hline Factors and categories & No. & $\begin{array}{l}\text { Average of } \\
\text { Requirements } \\
(*) \bar{X}\end{array}$ & $\begin{array}{c}\text { Calculated } \\
\text { F }\end{array}$ & $\begin{array}{c}\text { Table } \\
\text { F }\end{array}$ \\
\hline Level of education & & & \multirow{6}{*}{$5.44 * *$} & \multirow{6}{*}{2.37} \\
\hline Illiterate & 16 & 6.786 & & \\
\hline Reads and writes & 25 & 5.862 & & \\
\hline primary education & 57 & 5.495 & & \\
\hline secondary school & 26 & 5.563 & & \\
\hline high school & 18 & 4.540 & & \\
\hline \multicolumn{3}{|c|}{ No. of months of using the system } & \multirow{4}{*}{$38.94 * *$} & \multirow{4}{*}{2.99} \\
\hline (4-11) months & 54 & 6.765 & & \\
\hline (12-19) months & 69 & 5.250 & & \\
\hline (20-24) months & 19 & 4.153 & & \\
\hline \multicolumn{3}{|l|}{ Annual income } & \multirow{4}{*}{$33.52 * *$} & \multirow{4}{*}{2.99} \\
\hline Less than (6) million Dinar & 63 & 6.586 & & \\
\hline (6- 9) million Dinar & 42 & 5.381 & & \\
\hline More than (9) million Dinar & 37 & 4.474 & & \\
\hline \multicolumn{3}{|l|}{ Size of agricultural holding } & \multirow{4}{*}{$5.96 * *$} & \multirow{4}{*}{2.99} \\
\hline Less than (100) Donum & 20 & 6.163 & & \\
\hline$(100-150)$ Donum & 90 & 5.848 & & \\
\hline More than (150) Donum & 32 & 4.903 & & \\
\hline \multicolumn{3}{|l|}{ Access to information sources } & \multirow{4}{*}{$12.23 * *$} & \multirow{4}{*}{2.99} \\
\hline$(20-23)$ weak & 38 & 6.260 & & \\
\hline (24-27) moderate & 83 & 5.750 & & \\
\hline (28 and more) high & 21 & 4.351 & & \\
\hline \multicolumn{3}{|l|}{ Readiness to change } & \multirow{4}{*}{$\begin{array}{l}0.63 \\
\text { N.S. }\end{array}$} & \multirow{4}{*}{2.99} \\
\hline$(11-15)$ weak & 21 & 6.027 & & \\
\hline (16-20) moderate & 86 & 5.632 & & \\
\hline (More than 20) high & 35 & 5.587 & & \\
\hline \multicolumn{3}{|l|}{ Social norms } & \multirow{4}{*}{$\begin{array}{l}1.12 \\
\text { N.S. }\end{array}$} & \multirow{4}{*}{2.99} \\
\hline$(15-18)$ weak & 28 & 5,356 & & \\
\hline (19-22) moderate & 90 & 5.822 & & \\
\hline (more than 22) high & 24 & 5.609 & & \\
\hline
\end{tabular}

(*) Max 12

$\left({ }^{* *}\right)$ Significant 0.01

From the results it was shown that no significant differences exist in the average educational and training requirements of farmers according to social norms 
which maybe because farmers have educational and training requirements despite having social norms because of their lack of experience.

Third: regression analysis for the relation between the educational and training requirements of farmers and a number of independent factors:

Table (3): Step-wise multiple regression analysis

\begin{tabular}{|c|l|c|c|c|c|}
\hline \multicolumn{1}{|c|}{ Variables } & $\mathrm{R}^{2}$ & $\begin{array}{c}\text { Change } \\
\text { in } \mathrm{R}^{2}\end{array}$ & $\begin{array}{c}\text { Coefficient of } \\
\text { partial regression }\end{array}$ & $\begin{array}{c}\text { Calculated } \\
\mathrm{F}\end{array}$ \\
\hline 1 & $\begin{array}{l}\text { No. of months of using } \\
\text { the system }\end{array}$ & 0.4084 & 0.4084 & -0.1141 & $* * 25.57$ \\
\hline 2 & Annual income & 0.4966 & 0.0882 & -0.0001 & $* * 7.40$ \\
\hline 3 & Social norms & 0.5128 & 0.0162 & 0.1772 & $* * 18.34$ \\
\hline 4 & $\begin{array}{l}\text { Communicating with } \\
\text { information sources }\end{array}$ & 0.5492 & 0.0364 & -0.1554 & $* * 15.92$ \\
\hline
\end{tabular}

** significant at the level of $(0.01)$

Step-wise multiple regression analysis was adopted and it explains the variance in dependent factor through a number of independent factors by their existence and not isolating their mutual effect and organize them according to the degree of contribution in explaining the variance (Table 3). he independent factors that have significant relations to the model are number of months of using the system, Annual income, Social norms, Communicating with information sources, contributed in explaining $54.92 \%$ of the variance in the level of educational and training requirements of farmers in the field of operating \& maintaining the centerpivot sprinkler irrigation systems in $\mathrm{Al} \mathrm{Ta'mim,} \mathrm{while} \mathrm{number} \mathrm{of} \mathrm{months} \mathrm{of} \mathrm{using}$ the system contributed in explaining $40.84 \%$ of variance in level of educational and training requirements of farmers while annual income contributed in $8.82 \%$ and social standards in $1.62 \%$ and finally the level of communication with information sources contributed with $3.64 \%$ of the variance. it is also shown that the factor social norms has contributed in explaining the variance although no correlation with the level of educational and training requirements was shown by it alone. It is shown that the model is significant at 0.01 level. The research reached to a number of conclusions most important of them that the level of farmers information and skills in using the center-pivot sprinkler irrigation systems is low and there are a number of factors that might lead to the variance in educational and training requirements for the farmers. The researchers recommend the necessity of preparing training programs for the farmers according to their scientifically and objectively determined requirements considering the factors related to those needs.

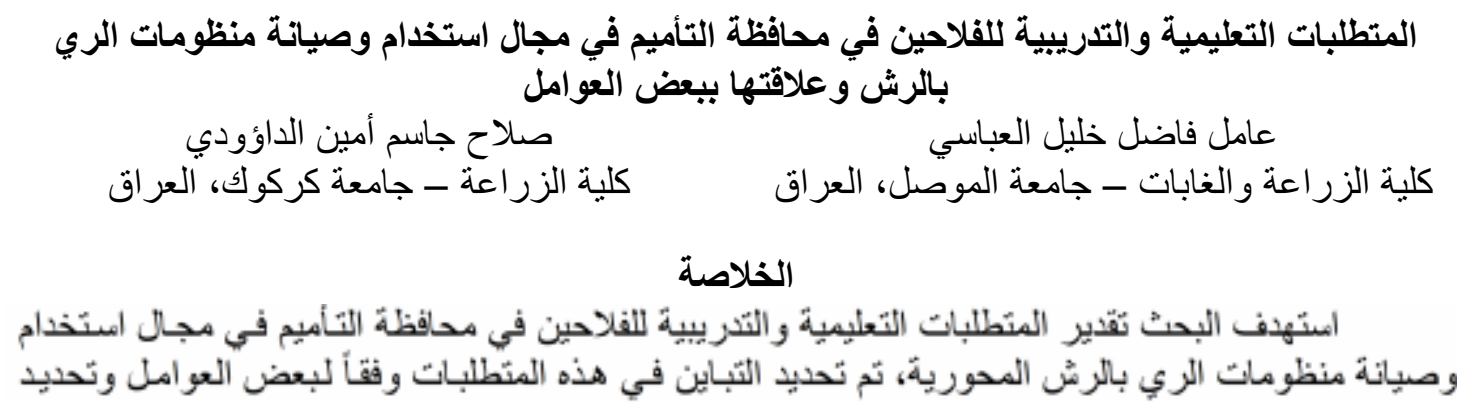




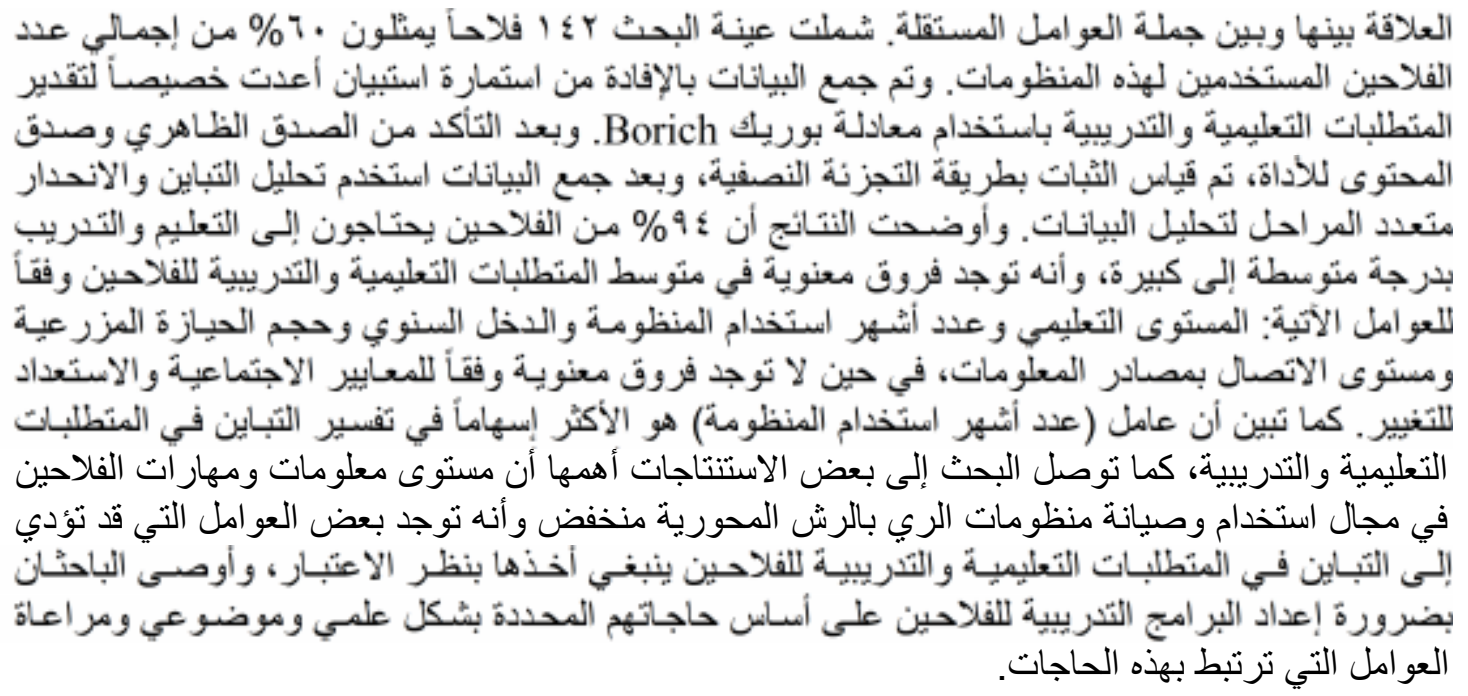

\section{REFERENCES}

Al-Abbassi, A.; D. N. Azzo and Y. S. Kassim (2002). The educational and training requirements of the farmers in the field of operating \& maintaining the center pivot-sprinkler irrigation systems and its relation with some variables. J. Agri. Sci, Tikrit College. Appendix of National Conference for plant production.pp 192-203.

Al-Azzawi N. K. (1999). Extension requirements for honey bee breeders in Baghdad. M.SC. Thesis, College of. Agri., Baghdad Univ., Iraq.

Al-Badri A. A. (1995). A study of the extension requirements of rural women in AlMahmodya. M.SC. Thesis. College of Agric. Baghdad Univ., Iraq.

Al-Juboori, A. A. (2000). The training needs of vegetable growers in Al-Sharqat and its relation with some variables. M.SC. Thesis, College. Agric., Mosul Univ., Iraq.

Al-Layla, Z. H. and A. F. Al-Abbassi. (1990). Comparing the training needs for agricultural extension workers in North Iraq according to some personal and voctational characteristics. Mesopotamia J. of Agric., 22 (4): 19-28.

Al- Marsumi, S. K. (1994). Agricultural requirements for cotton farmers and the factors effecting them in Al-Qayara. Mesopotamia J. of Agric., 26(2): 5-12.

Al-Mamuri, S. H. (1995). A study of training requirements of agricultural officials in some agricultural extension subjects and their importance to the work and their relation to a number of factors. M.SC. Thesis. College of Agric. Baghdad Univ., Iraq.

Al-Samarai, A. A. and A. H. Al-Jadri (1990). The agricultural extension science. Mosul University Press. Iraq. pp 376.

Al-Shadayda, A. N. (1999). The training needs of agricultural extension workers in Jordan and its relation with some factors. Ph.D. Thesis. College of Agric. Baghdad Univ., Iraq.

Arabic Organization of Agricultural Development (1999). An evaluation of modern irrigation technology under Arabian agricultural conditions. Al Khartom, December. 
Arabic Organization of Agricultural Development (2001). The study of the field of training and curriculum and training requirements in irrigation administration in Arabic countries. Al-Khartum. April.

Borich, G. D. (1980). A Needs assessment model for Conduction follow up studies. J. of Teacher Education, 31 (3): 37-44.

Ibrahim, A. A. (1991). Extension requirements for honey bee breeders in Manflut and Saleem Coast in Asyout governorate. Asyout J. Agric. Sci., 22 (4): 328339.

Mohammed, A. H. (1999). Using modern sprinkler irrigation systems as a tool confronting challenges and a method to achieve development. Iraqi Agric. J. Issue .23 .

Appendix 1. The educational and training requirements of the farmers in all items.

\begin{tabular}{|l|c|c|c|}
\hline \multicolumn{1}{|c|}{ Item } & $(*)$ Mean & S.d. & Rank \\
\hline How to use insecticide \& herbicides with sprinkled water. & 9.74 & 1.81 & 1 \\
\hline Knowing the type of malfunction from main board. & 9.30 & 2.15 & 2 \\
\hline How to use fertilizers with sprinkled water. & 9.08 & 2.30 & 3 \\
\hline Scheduling the irrigation for the crops yield. & 8.95 & 2.26 & 4.5 \\
\hline Knowing malfunctions in the electric generator. & 8.95 & 2 & 4.5 \\
\hline Lubricating the system. & 8.92 & 2.26 & 6 \\
\hline Changing the gearbox oil. & 8.21 & 2.32 & 7 \\
\hline How to lubricate the fuel pump. & 8.01 & 2.40 & 8 \\
\hline Knowing the specifications of the electric generator & 7.88 & 2.91 & 9 \\
\hline Changing the wheel engine oil. & 7.71 & 2.45 & 10 \\
\hline Knowing pumps malfunction. & 7.63 & 2.33 & 11 \\
\hline $\begin{array}{l}\text { Knowing the size of area that can be cultivated according to } \\
\text { water drain source. }\end{array}$ & 7.53 & 2.64 & 12 \\
\hline Knowing the tower malfunctions. & 7.50 & 2.29 & 13 \\
\hline Knowing how to use the irrigation water level counter. & 7.43 & 2.40 & 14 \\
\hline $\begin{array}{l}\text { Knowing the specifications of the pump that supplies water to } \\
\text { the system. }\end{array}$ & 7.38 & 2.76 & 15 \\
\hline Knowing the malfunctions of pressure regulators. & 6.97 & 2.79 & 16 \\
\hline Know how to use timer. & 6.90 & 2.41 & 17 \\
\hline $\begin{array}{l}\text { Knowing the number of hours for operating the pump according } \\
\text { to water drain. }\end{array}$ & 6.82 & 2.74 & 18 \\
\hline Knowing the use of terminal guns. & 6.77 & 2.99 & 19 \\
\hline Knowing how to inspect of terminal guns. & 6.74 & 2.93 & 20 \\
\hline Knowing the operating method of sprinklers (nozzles ). & 6.54 & 2.86 & 21.5 \\
\hline How to determine the sprinklers speed. & 6.54 & 2.08 & 21.5 \\
\hline $\begin{array}{l}\text { Knowing the appropriate water pressure that results in correct } \\
\text { operation of the system. }\end{array}$ & 6.31 & 2.51 & 23 \\
\hline Knowing the use of pressure regulators. & 5.60 & 2.82 & 24 \\
\hline How to clean the fuel tank properly for dirt and humidity. & 2.80 & 25 \\
\hline How to control the operation of the sprinkler (nozzles). & 2.63 & 26 \\
\hline Knowing the types of sprinklers (nozzles). & 5.53 & 2.90 & 27 \\
\hline How to operate the electric generator. & 3.87 & 28 \\
\hline How to connect the pump to the system. & 2.95 & 29 \\
\hline Know how to operate the system. & 2.35 & 31 \\
\hline
\end{tabular}




\begin{tabular}{|l|c|c|c|}
\hline \multicolumn{1}{|c|}{ Item } & $(*)$ Mean & S.d. & Rank \\
\hline Knowing the uniformity of water distribution in the filed. & 4.46 & 3.15 & 31 \\
\hline Knowing the operating hours before changing oil filter. & 4.46 & 2.68 & 31 \\
\hline Knowing the operating hours before changing gasoline filter. & 4.44 & 2.67 & 33 \\
\hline How to calculate the irrigated area. & 4.34 & 2.80 & 34 \\
\hline How to change gasoline filter. & 4.11 & 2.80 & 35 \\
\hline How to change oil filters. & 4.08 & 2.28 & 36 \\
\hline How to Check the generator voltage. & 3.98 & 2.99 & 37.5 \\
\hline How to clean the nozzles. & 3.98 & 2.77 & 37.5 \\
\hline How to change the pipes. & 3.93 & 3.32 & 39 \\
\hline How to wash the pipes after each irrigation season. & 3.83 & 2.88 & 40 \\
\hline Knowing the type of the pipes used. & 3.63 & 2.69 & 41.5 \\
\hline Knowing the defects and difficulties in irrigation by sprinkling. & 3.63 & 2.92 & 41.5 \\
\hline Knowing the lowest pressure of tires that can be utilized in & 3.42 & 2.95 & 43 \\
\hline operating the system. & 3.27 & 2.84 & 44 \\
\hline Knowing the basic parts of the sprinkler irrigation system. & 3.07 & 2.74 & 45 \\
\hline Checking the oil level in the pump. & 2.99 & 2.64 & 46 \\
\hline Checking the quantity of engine oil. & 2.15 & 2.35 & 47 \\
\hline How to stop the system. & 2.00 & 2.80 & 48 \\
\hline Knowing the benefits of irrigation using sprinklers. & 1.75 & 2.74 & 49 \\
\hline How to check tire pressure. & 1.65 & 2.29 & 50 \\
\hline Knowing the appropriate time to operate the system. & & \\
\hline
\end{tabular}

$(*)$ Maximum degree $=12$. 